\title{
Problems and Countermeasures of Archives Management of Secondary Colleges in Internet Times
}

\author{
Hongwei Lu \\ Shandong Technology and Business University \\ Yantai, Shandong 264005, China
}

\begin{abstract}
The archives formed in the process of teaching and scientific research in Secondary Colleges of colleges and universities are an important source and component of archives in Colleges and universities, and also play a vital role in teaching evaluation and auditing. However, at present, most secondary colleges do not have special archives management posts, which are usually held concurrently by teaching secretaries. From the perspective of teaching secretary, this paper analyses the problems existing in the management of archives in secondary colleges, such as the lack of professional archives managers, the lack of archival consciousness of teachers, the imperfection of rules and regulations, the poor software and hardware facilities of archives offices, the lack of centralization and standardization of archives management, and the low utilization rate. It also puts forward some reasonable suggestions, such as strengthening professional training, improving their comprehensive quality, perfecting the archives management system, strengthening the information construction of archives management, improving the utilization rate of archives, implementing incentive mechanism and improving the quality of staff, to provide theoretical support for the archives management of secondary colleges in Colleges and universities in the Internet era.
\end{abstract}

Keywords-Internet Age; Secondary College; Archives Management

\section{INTRODUCTION}

Internet is closely related to people's work and life, especially in work. The application of Internet technology cans effectively store and process data, greatly improving office efficiency. However, at present, there are still some problems in the application of Internet technology in archives management in many colleges and universities in China, which seriously affects the efficiency and quality of office work. Therefore, it is necessary to take appropriate measures to solve these problems. Secondary colleges in Colleges and universities are the grass-roots units of colleges and universities, and they are at the forefront of teaching, scientific research and management. All the work of the school must pass through secondary college to play a role [1]. According to the Regulations on the Administration of Archives in Institutions of Higher Learning, Decree No. 27 of the Ministry of Education and the State Archives Bureau of the People's Republic of China, the archives of institutions of higher learning mainly include: Party, administration, students, teaching, scientific research, infrastructure, instruments and equipment, product production, foreign affairs, publications, finance and accounting, etc. The archives management of secondary teaching units mainly involves the first five categories. At present, most colleges and universities have set up archives or comprehensive archives, established posts and personnel, and formulated archives management system. However, due to various influences, there are still many problems in the archives management of secondary colleges.

\section{OPPORTUNities OF ARCHIVES MANAGEMENT IN THE INTERNET ERA}

Archives management is indispensable in enterprises. It can not only provide an effective basis for the management of staff, but also provide support for enterprise decision-making. It is very inefficient for archives managers to use traditional methods to carry out archives management. And with the continuous expansion of the scale of the enterprise, more and more employees and business operations of the enterprise are gradually increasing. Accordingly, more and more files need to be managed, which is a very heavy task for archives managers. The advent of the Internet era has brought good opportunities for archives management.

\section{A. Enrich Technical Means}

Internet technology has changed the single situation of traditional archives management methods and enriched the management technical means. With the help of Internet technology, data information can be input, stored and retrieved effectively. If you want to use one of the files, you don't need to read the files one by one, you can search them directly on the network, which can effectively reduce the intensity of work for file managers. In addition, Internet technology can store not only data and information, but also video and audio, and the storage form is more diversified.

\section{B. Expand Service Space}

With the rapid development of society, the business of enterprises has gradually diversified, and the amount of information in archives management has been significantly increased. If the traditional file management method is used, it will take up a lot of storage space, at the same time, it will increase the cost of management. If the archives information is stored in the computer network, it can not only save space, but also complete the storage and management of massive 
information in the big data era, which greatly saves the cost of storage and management. Through the use of Internet technology, it can also realize the remote service of archives management and facilitate the filing.

\section{Improve the Timeliness of Archives}

In the new era, the application of Internet technology in archives management can significantly improve the timeliness of archives, which is also the most obvious advantage of Internet technology for archives management [3]. As the society is progressing and the development of enterprises is changing, a lot of archives content needs to change with the passage of time. The application of Internet technology can update archives quickly, which is faster and more accurate than paper archives. And with the continuous progress of science and technology, the timeliness of future archives management will be more obvious.

\section{Problems in ARChives MANAGEMENT OF SECONDARY COLLEGES IN UNIVERSITIES}

\section{A. Lack of professional Archivists}

At present, most secondary colleges have not yet equipped with full-time personnel with archives management background to manage archives, mainly by the office director or teaching secretary concurrently. As office directors and teaching secretaries generally have not systematically studied the professional knowledge of archives management and received professional training in archives management, they only collect information according to their working habits and acceptance in daily management. [4] The lack of archiving awareness of managers inevitably leads to the omission of some important documents. At the same time, the file sorting and filing process is not standardized and imperfect, which will also bring difficulties to the later search for information or handover work.

\section{B. A Weak Sense of Archiving of Teacher}

The archives of secondary colleges are not only composed of daily office documents and student documents, but also include the materials and achievements produced by teachers in the process of teaching and scientific research. However, due to some teachers' resistance to archiving, they believe that the results formed in the process of teaching and scientific research belong to private property and are unwilling to disclose, resulting in incomplete and inaccurate archiving of this part of information. Some teachers lend out archived documents and didn't to return them for a long time. Over time, teaching secretaries may be busy with their daily work and forget to remit, resulting in the loss of archives.

\section{Imperfect Rules and Regulations}

The archives management system of most secondary colleges is implemented according to the archives management system of the schools. There is no specific archives management system for the actual situation of the departments. This will easily lead to no normative constraints from person to object to file management process. Even if there is a certain management system, it is relatively simple, and lack of implementation and supervision is ineffective. In addition, the teaching secretary has no professional knowledge background, and has no basis to follow when encountering specific problems, leaving behind more and more problems.

\section{Poor Software and Hardware Facilities in Archives}

Due to insufficient funds or insufficient attention paid by leaders, most secondary colleges still use traditional manual methods to manage archives, mainly archiving paper-based materials, which occupies a great deal of space. In addition, due to the lack of information-based file management system, such as some important audio, video, pictures, electronic version of the document can not be fully preserved [5]. What's more, some secondary colleges have not set up a special archives room, which is easily lost when stored in office cabinets or stacked with other unused sundries. Even if the archives are set up, there are no firefighting, security, temperature and humidity control and other equipment, which can easily lead to data damage.

\section{E. Weak File Management Concentration and Standardization and Low Utilization Rate}

The original intention of archives management in secondary colleges is to leave traces of work in conventional teaching activities, scientific research and teaching reform, and support follow-up work, so as to benefit teachers and students. But the teaching secretary often only pays attention to the redheaded documents issued by the school in the data archives, ignores a large number of precious materials and first-hand achievements formed in the process of teaching and scientific research, and even pays attention to the quantity and ignores the quality to a certain extent, resulting in the incomplete archives. [6] At the same time, due to the lack of systematic reorganization, it takes a lot of time and energy to turn over the boxes and invert the cabinets when searching for archives. It also fails to find useful archives in time, and the ultimate goal of archives management can not be achieved.

\section{Suggestions ON IMPROVING ARChIVES MANAGEMENT IN SECONDARY COLLEGES}

There are various problems in archives management in secondary colleges, which seriously affect the effect of archives management. Therefore, we should adopt corresponding measures to solve the problems in order to improve the quality of archives management.

\section{A. Strengthen Professional Training and Improve Their Comprehensive Quality}

Archives management is a professional work, which requires professional knowledge. Under the background that the establishment of full-time archivists is not generally considered in secondary colleges, in order to improve the quality of archives management, secondary colleges may arrange for teaching secretaries to attend relevant skills training courses regularly, or to visit other institutions and study archives management, they can also consult with the school archives to send a full-time archivist to the college for on-site operation and guidance, so as to improve the professional 
ability and comprehensive quality of the teaching secretary's archives management.

\section{B. Perfect the Archives Management System}

As the saying goes, "no rules, no square circle". Everything needs to be handled in accordance with the rules and regulations. In order to make the archives management more standardized, the secondary college may formulate the archives management system according to the actual situation of the college, and make clear the scope of archives collection, the use of archives boxes, the storage period, the borrowing process and the transfer procedures, etc. Only when a rigorous system has been formulated can it be possible to standardize the file management process of teaching secretaries, and when problems arise, they can be dealt with in accordance with the standardization of the system.

\section{Strengthen the Informatization Construction of Archives Management}

With the rapid development of Internet technology, various management platforms emerge at the historic moment, system development technology is also mature, archives management should also enter the era of information management. Secondary colleges should increase their investment in archives funds and establish a system of the archives management platform. In addition to storing paper-based version of conventional data, electronic version of important audio, pictures and useful data should be formed and stored in the system. Managers can quickly find corresponding information by searching and consulting information for archives. At the same time, the system should also be open to the faculty and staff of our college, so as to facilitate the search of information and realize the real sense of file information sharing.

\section{Improve the Utilization Rate of Archives}

In order to improve the utilization rate of archives, the existing archives can be regularly arranged into special topics, compiled into volumes or formed special archives with the characteristics of our college for teachers and students to borrow, copy and issue certificates.[7] Archives offices can also set up open days to allow teachers and students to visit the archives and consult relevant information so as to make full use of archives resources.

\section{E. Implement the Incentive Mechanism}

It takes a lot of time and energy for the teaching secretary to input the data and information of archives into the computer. Moreover, the requirements for the entry of archives in Colleges and universities are stricter and no errors can occur. A lot of information is very complex and difficult to input, which can easily make the teaching secretary feel tired and work enthusiasm vulnerable. In this regard, colleges and universities should implement appropriate incentive mechanisms and give appropriate material and financial incentives to improve work enthusiasm. Only by guaranteeing high working enthusiasm and enthusiasm can we improve its working efficiency and ensure the quality of archives management.

\section{F. Improve the Quality of Staff}

Manpower management is a necessary condition for the development of archives management. In the era of rapid development, the requirements for archives managers are constantly increasing. Therefore, colleges and universities should strengthen the training of teaching secretaries, regularly send professionals to train employees, so that they can master advanced management concepts and methods, dynamically understand the development trend of society, and improve their ability to apply information technology. In addition, colleges and universities should also strengthen the training of archives managers' safety awareness, improve their ability of safety prevention, so as to improve the level of archives management and provide data basis for sustainable development of colleges and universities.

\section{CONCLUSION}

In the Internet era, only by defining its own problems, changing management concepts, actively introducing advanced Internet technology and improving the comprehensive quality of archives managers, can the archives management level be truly improved and the archives management meets the development needs of secondary colleges in Colleges and universities. The archives of secondary colleges are the firsthand materials produced in the process of teaching and scientific research, and are an important part of school archives. However, the current construction situation is not optimistic, there are many problems. In order to better construct and manage the archives management of secondary colleges, on the one hand, we need to continue to strengthen the traditional way of archives management; on the other hand, we can use the Internet and network technology to establish a digital archives management model, realize resource sharing, adapt to the development of the times, and improve the quality of Archives management.

\section{REFERENCES}

[1] Wang Yuan. Zhou Wei. Problems and Countermeasures of Archives Management in Secondary Departments of Colleges and Universities [J]. Office Business, 201102 (02): 132-133.

[2] $\mathrm{Li}$ Yang. Discussion on the Innovative Development of Archives Management in the Internet Age[J]. Landai Inside and Outside,2019(2):21-23.

[3] Li Xueying. Exploring the Opportunities and Challenges of Archives Management in the Internet Age[J]. Modern Marketing(Business Edition),2018(6):53.

[4] Song Yili. Challenges and Countermeasures of Archives Management in the Internet Age[J]. Office Business, 2011(8): 28.

[5] Lin Jinian. Opportunities and Challenges in Archives Management in the Internet Age[J]. Office Business, 2017(7): 90.

[6] Mu Yarong. Study on the Construction and Management Strategy of Teaching Archives from the Perspective of University Teaching Secretaries[J].Science and Education Educational Journal (Midterm),2015(08):17-18.

[7] Liu Wenqiu and Li Liwei. On the Problems and Countermeasures of Teaching Archives Management in Secondary Colleges in Colleges and Universities[J].Education Modernization,2017. 4(47):253-254. 